\title{
Partial Fulfillment of the Requirement for the Degree Doctor of Philosophy in Business Administration
}

\author{
Yan-Zhe Zheng ${ }^{1, \mathrm{a}^{*}}$ \\ ${ }^{1} 3 \mathrm{~F}, \mathrm{Bdg} 1$, Lianjian technology \& industrial park, Dalang, Longhua, Shenzhen, China \\ a445334089@qq.com \\ ${ }^{*}$ Corresponding author
}

Keywords: Business model innovation, SMEs, Innovation, System science, Empirical research.

\begin{abstract}
Research on business model, whether at home or abroad, is a hot issue. Since the $21^{\text {st }}$ century, with the further development of science and technology, continuous improvement of productivity and further intensified competition in the market economy, business model innovation gains more and more attention of scholars and entrepreneurs. Small-and-medium enterprises (herein referred to as SMEs), as an absolute majority of the total number of enterprises, their business model innovation is more important. Theoretical research on business model focuses on connotation, elements, evaluation and design of business models, and has made a lot of achievements. This paper attempts to conduct research on SMEs' business model innovation, aiming to provide insights for the business model innovation of SMEs.
\end{abstract}

\section{Research Background}

Globalization and informatization are external background of the research of business model innovation. Increasingly frequent economic activities at the international level, development of global trade, growing foreign direct investment, international penetration of transnational corporations, coupling with the development of financial innovation and global wave of liberalization in the late $20^{\text {th }}$ century ultimately form the pattern of economic globalization. Economic globalization realizes cross-border free flow of goods, services and capital, with more worldwide industry consolidation. If enterprises want to survive and win in fierce market competition, enterprises must face competitors directly. Globalization not only has a vast market and profit margins, but also has the most extensive and intense competition.

As the representative of the third technological revolution, informatization is one of main drivers of globalization, but also one of the most powerful means for enterprises to win competitive advantages of globalization and its power is increasingly apparent. The development of mobile communications technology and network technology has great impact on enterprises' production way and consumers' consumption patterns, new production mode and way of living present tremendous opportunities.

SMEs in adversity is the internal background of business model innovation..

\section{Research Significance}

From the business perspective, SMEs are the driving force of the rapid growth of national economy. The scale of the enterprises is codetermined by technical equipment, industry characteristics, market demand and other factors. Larger enterprise scale does not necessarily translate into higher proficiency. SMEs also make important contribution to employment and GDP. The number of SMEs in United States, European Union, France, Japan and other countries accounts for over $98 \%$ of total number of enterprises and they have insurmountable advantage in quantity, the number of people employed in SME sector accounts for $65 \%$ to $80 \%$, i.e. more than half of the jobs; GDP and the output value respectively account for $40 \%-60 \%$ and $50 \%-65 \%$, creating huge national wealth. For a nation and a region, SMEs play a role of promoting economic development 
and stabilizing social politics. The practice of the economic development in all countries of the world proves that, only when SMEs enjoy prosperity, can economy and society register substantial growth. In modern society, the business model of an enterprise is a main factor of its enterprise value. The rapid growth of SMEs rely mainly on two aspects, namely, favorable external market and industry conditions, inherent technology, human and other resource advantages. But how to use limited resources within the enterprise to grasp "unlimited" (in terms of the relative capacity of SMEs ) market demand needs reasonable business model to link them together. Therefore, the study of SMEs' business model innovation has great significance.

As SMEs play an important role in national economy, and business model innovation is related to the national economy, as the most extensive base and support of China's economy, the development of SMEs is always in the spotlight. Without the aura of industry-leading position, the most extensive market channels, strong voice, abundant funds, mature team and exclusion and suppression from large enterprises, SMEs will easily fall victim if they aim to catch up with certain companies. Facing strong competitors, SMEs in disadvantaged positions should grasp the pulse of the general environment, create values for customers and win development by innovative and inventive ways. Business model innovation is the basis and guarantee for SMEs to keep rapid growth. To some extent, the essence of the transformation of SMEs is the transformation of business model. Today, as network economy develops rapidly, enterprises' business model has become the focus of enterprises' fostering new competitive advantages. Although SMEs are limited by uncertainty of resources, capacity and environment, they also have strong entrepreneurial orientation and innovation desire. With huge domestic and overseas market potential, SMEs have opportunity and capacity to become the subject of business model innovation with the improvement of core competitiveness of enterprises as the goal. Business model innovation is an important way for SMEs to integrate resources, enhance competitiveness and maintain competitive advantages. It is a key capacity that enterprise should be equipped with for adapting to environmental change and participating in market competition. SMEs will only have development opportunities that belong to them by adhering to business model innovation.

From the perspective of market, current study on business model innovation has profound historical background and practical significance. First, information technology revolution provides space and power for business model innovation. In today's digital age, network and mobile communication technologies are changing human being's production ways and lifestyles in all directions. More and more information technologies integrate into social life and promote the change of enterprises' production and operation mode. New technology creates conditions for the establishment of a more favorable business model, and it also needs to cooperate with new business models so that it can play a role. Second, changes in consumer demand require enterprises to conduct business model innovation. With the rapid development of social economy, consumer demand gradually shows tendency of personalization, independence and complexity. These changes objectively require further innovation of business model, and creation of more value for customers, as well as a more efficient way to build competitive advantages.

\section{Definition of Related Concepts}

\section{SME}

As the object of this study, the concept of SME is particularly important. The division of enterprise scale is a relative term. So-called SMEs refers to those economic sectors which have smaller scale of staff, asset and operations when comparing with big enterprises in the same industry. The second stipulation in SME Promotion Law of the People's Republic of China: SME mentioned in the law refers to enterprises of all different kinds of ownership and form that are established according to the law in the PRC to help to meet social needs, increase employment in line with national industrial policy with small and medium production scale." The specific criteria of categorizing SME is formulated by State Council according to the number of enterprise employees, sales, total assets and other indicators with reference to industry-specific characteristic. 


\section{Business Model}

"Business model" coming from English first appeared in academic papers in the late 1950s, but until the late 1990s, as a large number of emerging IT companies' business model gained great success, business circle and academic circle began to pay attention to and study business model of enterprises.

The subject of business model innovation is enterprise and the purpose of innovation is to better meet customers' needs. Therefore, combining with systematicness and relative stability of business model, the thesis considers that business model is a system of enterprises' allocating enterprise resource through business organizations by centering on creating customer value in a certain period of time.

\section{Innovation}

Innovation is the most obvious and powerful offensive advantage. In an open market environment, competition is becoming increasingly fierce. Without innovation, enterprises will eventually be wiped out by the development and the market. Innovation has not only been limited to new product development and services, but also brings a business model of a change in organizational structure and continuous business growth for enterprises.

SMEs must pay attention to shape enterprise brand, and exert in the credit aspect, list a complete quality guarantee in writing in the commodity exhibition, advertising and shipping documents, to train consumers' trust for goods virtual show. At the same time, SMEs should exceed customer expectation, provide better personalized service, stronger price strategy for the customer to realize the interaction, matching words with deeds, practicing commitment, provide not only products, but also knowledge, drive the whole e-commerce to better develop in the direction of specialization, normalization, standardization, branding.

\section{References}

[1] Afuah A. \& Tucci C. (2001). Internet business mode lsand strategies:Textandcases. Boston: McGrawOHill /Irwin. pp. 32-33.

[2] Chen Q.R. \& Yang C.S. Business mode development review. Economic Research Guide. (19), pp. 201-202.

[3] Christensen C.M. (2000). The innovator.s dilemma: When new technologies cause great firms to fail. MA:Harvard Business School Press. pp. 188-2151.

[4] Christoph Z. \& Raphale A. (2007). Business mode design and the performance of entrepreneurial firms. Organization Science, 18(2), pp. 181-199.

[5] Diao Y.Z. \& Bai J.K. (2012). Mechanism of business model innovation: a theoretical framework of systems thinking. Journal of Management. (01), pp. 71-80.

[6] Fan Y.J. (2009). Business mode design and innovation. Ocean University of China.

[7] Fang J.C., Zhang X.M. \& Zhu B. (2010). Analysis and empirical research on China SMEs business mode innovation path - An example of SMEs in Fujian. Journal of Changhun University of Technology(Social Sciences Edition). (07), pp. 55-57.

[8] Gao L.L. (2010). Research on business mode innovation path. Wuhan University of Technology.

[9] Guo L. (2009). To study on innovating and evolving mechanism of the business model based on the theory explanation of the value chain. Value Engineering. (10), pp. 71-73.

[10]Guo L.N. (2011). Inquiry on reasonable configuration and use of enterprise human resources. China Business Update. (08), pp. 97. 